\title{
Supplementary Feeding of Range Sheep
}

\author{
D.L. MICHALK AND D.G. SAVILLE
}

\begin{abstract}
Droughts significantly reduce the production from range sheep and in severe cases affect survival. In order to avoid losses in times of feed shortage, pastoralists must either supplement sheep at pasture or implement total hand-feeding strategies. To employ either practice necessitates familiarity with the principles of supplementary feeding, many of which are summarized in this paper. In addition to discussing the nutrient requirements of grazing sheep, the expected responses to supplementary feeding for different classes of sheep and production activities are reviewed. The question of when to commence feeding is discussed and information is provided on the formulation of diets with respect to the physical form and the nutritive value of the ingredients. Finally, research highlighting the importance of feeding frequency is reviewed.
\end{abstract}

Efficiency of animal production is closely related to both the nutritive value and dry matter availability of the forage resource. In intensive feedlots and grazing on tame pastures, the provision of an adequate diet for sheep production causes few difficulties to the rancher. However, due to the dynamic nature of range vegetation, the provision of adequate nutrition for range sheep poses a greater challenge for pastoralists. One cannot meet this challenge without a detailed knowledge of the physical characteristics of the range site and the nutritional requirements of sheep for growth and production.

On most rangelands the quality and quantity of forage varies appreciably with climate and often leads to nutritional inadequacy, with insufficient energy for maintenance rations, severe phosphorus limitations, and protein deficiencies being reported for many sheep ranges (Whitcomb 1952; Argle 1956; Harris 1960). Such deficiencies can result from bleaching and leaching of forage by rainfall (Hart et al. 1932; Watkins 1937; Whitcomb 1952). For phosphorus, Watkins (1937) reported reductions of $75 \%$ due to leaching, while protein levels below $4 \%$ have frequently been reported (Davies et al. 1938; Harvey 1952; Harris 1960). Since this dry material furnishes a cheap energy source for livestock if properly supplemented, the

\footnotetext{
Authors are rescarch agronomist and director of research, Agricultural Research Station. Trangie, New South Wales, Australia, 2823 (Michalk is a present with the Department of Range Science. Utah State University Logan 84322).

The senior author would like to acknowledge the financial support provided by the Australian Meat Research Committee for graduate studies at Utah State University. In addition the helpful comments and criticisms advanced by Drs. J.C. Malechek and D.D. Dwyer are gratefully acknowledged.

Manuscript received September 11. 1978
}

responses resulting from feeding supplements to sheep grazin range forage are a subject of increasing importance and interes

\section{Type of Supplementation}

While deficiencies in a single element or an imbalanc between several nutrients may be corrected by supplementatio with the prime objective of increasing animal productior periods of severe drought can reduce dry matter production $t$ such low levels that encrgy becomes the limiting nutrien Inadequate energy is the most common nutritional deficienc affecting sheep production in Australia, and on arid ranges $i$ the Great Basin, Harris (1960) ranked energy with phosphor and protein as limiting factors to the winter grazing of sheer Supplementation under drought conditions requires the ranchs to provide a significant proportion of the animal's dietar intake. This is commonly referred to as "drought," " $\mathrm{r}$ placement," or "survival" feeding. While the type of ration fe is similar in both forms of supplementation, the level of feedin will vary between production and survival feeding, as wi managerial and economic considerations.

Harris (1960) advocated that an inexpensive supplemer should be fed up to the optimal level of response, whereas reduction in feeding levels should accompany price increase؛ This applies directly to production feeding since the onus $\mathrm{fc}$ decisions rests entirely on the shoulders of the ranches However, the economic considerations in a drought situatio are more complex because management decisions are made : both the rancher and governmental levels. These parties intera to the extent that the rancher's decisions to conserve fodder ma be influenced by the anticipated availability and price c alternative forage sources during drought, the cost of agistme and government decisions on the ease of securing credit, and th existence of subsidies for fodder and livestock transportatior

Despite the differences in objectives and decisions $f c$ production and drought feeding strategies, the most importat common considerations of supplementing available forag include: what to feed, how much to feed, when to feed, and ho' frequently to feed. It is the central motif of this paper to discus some of the principles of supplementary feeding and th technological advances that have resulted from research c supplementation. 


\section{Nutrient Requirements of Grazing Sheep}

It is necessary to acknowledge at the outset that a precise knowledge of the nutrient intake of grazing sheep is difficult to obtain since the amount and composition of ingested feed cannot be readily measured. However, results from "total handfeeding" experiments do indicate the minimal nutritional requirements necessary to ensure survival.

\section{Energy}

A minimal requirement for energy is a minimal nutritive requirement for an animal to meet its needs for maintenance and production, therefore most feeding systems are based on the animal's energy requirements. Both Blaxter (1967) in Britain and Oddy (1978) in Australia have suggested that a system of estimating energy requirements based on calculations of metabolizable energy (ME) has the greatest flexibility and potential for development to meet existing and changing circumstances. However, in the United States preference is given to the Californian net energy system advocated by Lofgreen and Garrett (1968).

Energy is used by animals to maintain life processes. The arbitrary minimal cost (referred to as "fasting metabolism") is relatively constant per unit of metabolic weight. In addition to maintenance requirements, animals must meet their energy costs of finding, eating, digesting, and assimilating food (Graham 1967). These energy requirements will be influenced by liveweight, the physiological state of the animal, and environmental factors such as temperature, wind, precipitation, and incident radiation. Oddy (1978) has outlined allowances that should be made for these factors. Young and Corbett (1972) related more precisely maintenance energy requirements to liveweight by the equation: $M=4.51 W+256$, where $W$ is mean liveweight and $M$ the estimated metabolizable energy $(M E)$ required in kcal per 24-hour period.

During reproduction additional energy is required for fetal development. A series of equations relating energy requirements $(M E)$ to liveweight at various stages of ewe pregnancy have been developed by the Ministry of Agriculture, Fisheries, and Food (1975) in Britain. On average, late pregnancy requirements increase to about 1.5 times that of a dry ewe. The further energy required for milk production is substantial, amounting to 3.2 times the dry ewe requirement.

Although energy may be inadequate on browse range (Stoddart et al. 1975), supplying carbohydrate should be done with caution since the provision of easily digested carbohydrate can depress the utilization of fiber (Topps 1972). A useful rule is to supply only enough energy supplement to increase forage consumption, but not to replace it. Thus, when calculating feed requirements it is necessary to know the energy concentration in the diet and the required or minimal liveweight of the animal. Saville (1978) has formulated a calculator which enables feed requirements on an energy basis to be identified quickly and simply (Fig. 1).

\section{Protein}

One of the important characteristics of low-quality roughage is its low protein content. Although sheep have the ability to select high protein forage, low protein levels in pasture will affect their performance because dietary protein deficiency is associated with a relatively low voluntary feed consumption. With protein-deficient diets, the metabolism of the rumen micro-biota may be depressed by a deficiency in rumen nitrogen; this limitation will retard the rate of removal of organic matter from the rumen which, in turn, may reduce intake

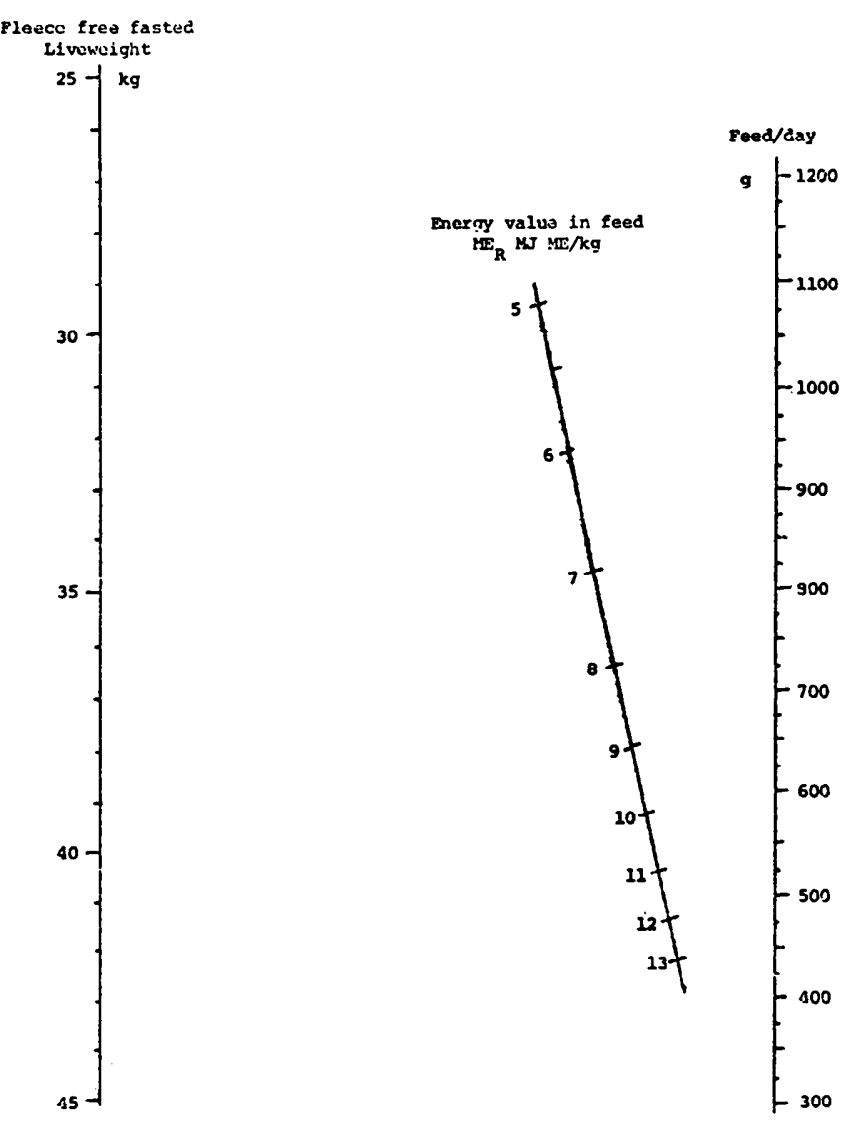

Fig. 1. Maintainance requirement for sheep.

(Weston 1971).

In terms of voluntary intake and the performance of lambs, it appears that little is to be gained by increasing protein levels beyond $15 \%$. The minimum crude protein percentages in the diet range from $6 \%$ for dry ewes and wethers to $12 \%$ for weaners weighing about $20 \mathrm{~kg}$ (Ministry of Agriculture, Fisheries and Food 1975).

The need for supplementation of protein can be determined by evaluating the nutritional quality of range forage by digestion techniques or by field experiments in which suspected deficiencies are supplied and animal responses measured (Stoddart et al. 1975). Allden and Jennings (1969) reported that protein deficiencies can be detected by fecal nitrogen analysis and set 1.6 to $1.7 \%$ as the threshold, below which supplements are required.

\section{Vitamins and Minerals}

The provision of adequate energy in pasture or supplements normally provides sufficient vitamins and minerals. Thus, in areas where phosphorus deficiencies occur, the condition is corrected by protein which is often concurrently deficient. Notable exceptions to this generalization are vitamin A and calcium. Grain-fed breeding ewes require vitamin A following long periods of supplementary feeding ( 30 weeks), and it is recommended that rams be supplemented with 1 million units 2 months prior to joining (Franklin 1962). The same author also reported that doses of vitamin A $(500,000$ units) increased the survival of grain-fed weaners by $50 \%$ after an 8 -month experimental period.

In their studies on sheep, Franklin et al. (1948) showed that pregnant ewes nourished on grain will be the first to exhibit symptoms of inadequate calcium, followed by suckling lambs 
and weaners. However, calcium deficiencies can be corrected by the addition of $1.5 \%$ limestone in their diet.

While other minerals may not generally be required for sheep grazed on rangelands, some local conditions may necessitate supplementation. For example, copper has been used in parts of New Zealand (Hogan et al. 1971) and Oregon (Stoddart et al. 1975) to correct the ill effect of high molybdenum; and in Australia (Lee and Maston 1969) and some parts of the United States (Clanton and Rowden 1963), cobalt additives have proven effective in sheep production.

\section{What Sheep Should Be Supplemented?}

In addition to a detailed knowledge of the economic considerations of supplementary feeding and the nutrient requirements of grazing sheep, the pastoralist must have an appreciation of the responses that are likely to emanate from feeding sheep for specific purposes such as wool production, reproductive performance, or liveweight gains.

\section{Supplementary Feeding and Wool Production}

Like other forms of animal production, wool growth is related to feed intake (Ferguson et al. 1949), although it responds slowly to changes in feed intake because it is "obligatory" to sheep regardless of nutritional level. Once adult size is reached, a sheep could theoretically be kept for the remainder of its life at maintenance intake and yet be an efficient wool producer. However, pre-natal nutritional penalties can cause a significant reduction in secondary wool-producing follicles (Hardy and Lyne 1956), a defect which is never repaired. In contrast, primary follicles are genetically determined. Furthermore, prenatal under-nutrition reduces birth weight, which leads to a significant reduction in adult size and hence potential wool production (Schinckle and Short 1961). It seems, however, that periods of malnutrition after weaning have only a temporary effect on wool production (Donald and Allen 1959).

Essentially, wool growth is determined by protein absorbed in the intestine, which in turn depends on ingested nitrogen sources. However, when dietary protein exceeds $8 \%$, wool growth is independent of protein and instead energy becomes the limiting nutrient (Ferguson 1959). As only about $2 \%$ of ingested net energy is converted to wool (Ferguson 1962), a large amount of energy is required to produce $1 \mathrm{~kg}$ of clean wool in adult Merino sheep maintaining liveweight. From the prices of wool and supplement, it is possible to calculate "break even", economics for different rations. However, owning to the low conversion efficiency, it is rarely economic to provide supplementary rations for wool production alone. In addition, supplementary feeding does not usually give the expected response since the supplement can act as a replacement for pasture that would otherwise have been consumed.

High protein supplementation of low protein diets is likely to produce a more efficient response in wool production since an appreciable increase in the protein percentage without a corresponding increase in energy intake can stimulate wool production without a comparable effect on liveweight, provided that the original diet contains less than $8 \%$ crude protein (Ferguson 1959). This response occurs because when protein intake falls, cystine becomes the first limiting factor in wool production (Marston 1932). However, even this feeding strategy is likely to be uneconomic when judged by wool production alone, although cases of protein supplementation have been economically justified in order to improve the condition of starved sheep in drought situations (Ryder and Stephenson 1968).
Responses in wool growth to protein supplementation have been reported in the literature. Orr and Holm (1931) reported a $30 \%$ increase in wool production due to the feeding of protein supplements on South African range, while Marston (1932) measured similar responses for Merino sheep in Australia. In Utah, Harris (1960) observed responses in wool growth of the order of $10 \%$ by supplementing arid ranges with small amounts of protein. However, the common factor in all these experiments was low pasture protein levels (less than 4\%).

\section{Supplementary Feeding and Reproductive Performance}

Low lambing percentages relative to the annual maintenance cost of the breeding flock has, for many years, been accepted as the main reason for the low efficiency of sheep production enterprises on rangelands. Reproductive wastage occurs not only through physical losses at critical breeding phases such as mating, late pregnancy, and lactation, but also through a failure to attain full reproductive potential. While some variation in wastage is due to seasonal influences, breed of sheep, and age, nutrition can also significantly influence the reproductive performance of both rams and ewes.

While the effects of adequate nutrition on the subsequent reproductive performance of ewes have been widely recognized, relatively few studies have highlighted the importance of the effects of under-nutrition on libido and semen quality of rams. Watson et al. (1956) stressed the importance of flushing rams, with results showing a positive correlation between ram puberty and liveweight. The relationship was independent of age. Poor nutrition significantly delays sexual maturity. Further, semen production is significantly reduced by inadequate nutrition (Tilton et al. 1964) such as is commonly associated with dry pasture, and libido will also decline (Parker and Thwaites 1972). The feeding of supplements has proven successful in ensuring early maturation of rams and high subsequent fertility.

Undernutrition of ewes during the first year or so of their life may have a detrimental effect on subsequent fecundity. Inadequate nutrition will shorten the oestrus cycle and lower the conception rate in mature ewes (Hafez 1952), although such nutritional conditions are likely to be experienced only during drought (Watson 1962). Nevertheless, McDonald (1962) commented that ewes fed to produce a rapid increase in liveweight prior to joining resulted in higher mating and weaning percentages. Working with range sheep in Utah, Richards (1942) found that ewes receiving a supplement of 0.4 $\mathrm{kg}$ of cottonseed cake per head per day produced more offspring at lambing and had a greater survival rate to weaning than did unsupplemented groups of ewes. It appears, however, that for good flushing results, ewes should be on a below-optimum plane of nutrition before the flushing period followed by an above-optimum plane of nutrition during the flushing period (Clanton 1957). At the other extreme, fatness resulting from excessive supplementation prior to joining may lead to conception failure.

Nutrition during early pregnancy needs to be sufficient to either maintain or slightly increase liveweight. In contrast, a plane of nutrition that does not produce gain or causes actual liveweight loss during late pregnancy will lead to high ewe losses through pregnancy toxaemia, severely reduce the birth weight, survival rate, and subsequent growth of lambs, and cause a low conception rate at the next mating period of the ewes (Thompson and Thompson 1968). Hoversland (1954) observed the highest number of premature births, lambs born dead and post-parturition mortality in ewes fed low levels of nutrition 
throughout gestation. Provision of adequate nutrition either at pasture or by supplementary feeding have great economic potential in reducing ewe and lamb mortality, as well as increasing the subsequent growth potential of lambs.

\section{Supplementary Feeding and Growth}

Under range conditions, young lambs are wholly nourished by their mother's milk. Well-fed ewes commence copious lactation at or shortly before parturition, while in undernourished ewes the onset of lactation may be delayed, which is a major factor contributing to neonatal deaths. Moule (1954) reported that over half of the $37 \%$ of lambs lost between birth and weaning on Australian range occurred during the first 3 days of life. Although studies have shown little direct relationship between supplementary feeding and milk production (Treacher 1971), it is apparent in cases of energy deficiency that milk production is maintained by depletion of body reserves (Hadjipieris et al. 1966). The lack of direct response in milk production to supplements may be the result of diet composition, since diets that promote a low acetate to propionate ratio in the rumen (Armstrong and Prescott 1971) will result in the deposition of adipose tissue at the expense of milk fat (Annison and Armstrong 1970). In addition, Graham and Searle (1970) calculated that the efficiency of converting feed to milk then to lamb growth is about $24 \%$, compared with a value of about $30 \%$ when ruminant lambs feed directly.

Lambs commence to eat some pasture after the first couple of weeks and can be weaned onto solid food at an early age. From the viewpoint of lamb growth, feed may be inefficiently used when young lambs are fed with their mothers since ewes will increase their own liveweight at the expense of lamb growth. As a result of this competition, alternative feeding strategies such as creep feeding or early weaning are benefical. While creep feeding will substantially increase lamb growth, facilities are not always available; therefore early weaning is a more practical method. The minimum age to wean lambs is about 6 weeks, or alternatively when their liveweight exceeds $8 \mathrm{~kg}$ (Franklin et al. 1964).

If weaning occurs when spring pastures are maturing, the growth of lambs may cease completely and not resume until green pasture grows after autumn rains. This situation calls for supplementary feeding. Esplin et al. (1940) measured greater liveweight gains in lambs supplemented in their first winter than in unsupplemented animals. This beneficial effect was carried over into the second year with supplemented ewes producing $20 \%$ more lambs. This was attributed to more fully developed reproductive tracts in the supplemented yearling ewes.

Normally lambs are fed in enclosures to minimize energy expenditure on unnecessary activities. The selection of the type of feed is important since growth rate and body conformation will vary with differently formulated rations. Diets for weaners that contain moderate levels of roughage are superior, possibly due to roughage enhancing development of rumen function. Reports on feeding whole grain diets are encouraging. For example, early weaned lambs fed barley-based diets showed excellent feed conversions of 3:1 (dry matter basis) during fattening periods from 15 to $45 \mathrm{~kg}$ liveweight (Andrew and $\varnothing$ rshov 1970). However, the selection of grain type is important for marketable animals, as grains producing large amounts of propionic acid result in the problem of soft subcutaneous fat ( Ørshov et al. 1974) due to the presence of mono-methy, branched-chained fatty acids. For marketable carcasses, molar proportions of propionic acid in the rumen must be kept below $12 \%$.

\section{When Should Supplements Be Fed?}

The above discussion outlines the possible areas of animal production which are sensitive to malnutrition and indicates the possible responses that may result from supplementary feeding. However, the problem of when to commence feeding still remains unanswered. Leng et al. (1973) stressed the need for predicting if and when grazing sheep will respond to supplements and to clarify whether responses are due to additional cncrgy or protein. This is not an easy task because the level and composition of intake cannot be measured easily. In spite of these difficulties, different criteria have been suggested as indicators of periods when intake may limit the productivity of grazing sheep. These include: a fall in dry matter digestibility below 45\% (Hutchinson and Porter 1958), a pasture crude protein level below 7\% (Vercoe et al. 1961), or a nitrogen content of less than $1.6 \%$ in fecal organic matter (Allden and Jennings 1969). While these criteria have applicability to experimentation, the pastoralist relies almost entirely on an assessment of the "condition" of his sheep and a visual evaluation of pasture availability.

\section{Diet Selection-What to Feed?}

Once it has been established that the available pasture is inadequate to meet the nutritional requirements of the grazing sheep, the rancher is faced with a decision regarding the composition of the supplement that can be provided in an economical fashion.

\section{Pasture as a Standing Green Supplement}

Since grazing is the most efficient way to provide nourishment to livestock, standing green pasture is often used to supplement low quality roughage in areas where climatic conditions permit. In Australia, a sheep property commonly has areas of tame pasture available for grazing. However, this area is usually insufficient to sustain all the livestock on the holding. The pastoralist may decide to graze his most important classes of livestock on these "improved" areas and carry the remainder on low maintenance quality pasture. Alternatively, both improved and natural pasture can be integrated into a pasture system (Myers 1967), since it has been reported that relatively small quantities of green pasture can greatly improve the production of grazing sheep (Willoughby 1959).

Experiments with cattle in northern Australia (Norman and Stewart 1967; Norman 1968) successfully incorporated periods of grazing high quality green pasture into a management system based on low-quality roughage during the winter months. The results showed a linear relationship between liveweight gain and the length of time spent grazing green pasture. Similarly, Lee and Rothwell (1966) used one-sixth of the total grazing area as lucerne (Medicago sativa) and reported a significant increase in carrying capacity, liveweight gain, and wool production of Merino sheep. In contrast, Campbell et al. (1973) observed no response to green feed supplements in a grazing system composed of one-third lucerne or perennial pasture and the balance of natural annual pasture. They commented that the failure to obtain a supplementary response was due to the ease with which the unsupplemented annual pasture supported the highest stocking rate of $4.9 \mathrm{dry}$ sheep $\cdot \mathrm{ha}^{-1}$. They concluded, however, that a supplementary response may be realized with a livestock enterprise which is more sensitive to changes in pasture quality and quantity than the wethers used in the study.

Further studies with a breeding ewe enterprise (Michalk 1977) did not substantiate this conclusion since no increase in 
ewe liveweight, seasonal wool growth, or lamb liveweight gain were recorded in supplemented treatments. This failure may be due to two factors: either access to green pasture by sheep was not frequent enough, or the proportion of lucerne used in the integrated system was insufficient to produce a supplementary effect. Animal house and field studies (Robards and Pearce 1975; G.E. Robards and K.J. Klinn, unpublished data) indicate that with a frequency of movement from high to low quality pastures of once every 5 weeks, the supplementary value to sheep would be small. To achieve a supplementary effect in production, access to green supplement must be more frequent, for example one day in five (Robards and Flinn, unpublished) or one hour per day (Miller et al. 1965). However, this management is unacceptable to pastoralists operating under extensive grazing conditions.

By theoretical calculation, Michalk (unpublished data) suggested that increasing the proportion of lucerne from one-third to two-thirds would result in less than a $15 \%$ increase in lamb growth, irrespective of stocking rate. Thus, when natural pasture is only marginally limiting in protein and furnishes sufficient energy, the value of green supplements in the economic sense may have practical application only in the case of flushing livestock prior to joining.

\section{Roughage-Concentrate Diets}

Ruminants often have available only low quality roughage, which is characterised by protein contents below $4 \%$ and fiber levels in excess of $18 \%$. In many instances, roughage may not provide sufficient energy for maintenance due to intake being restricted by physical factors such as rumen distension and rate of passage of undigested feed (Thornton and Minson 1972). High energy concentrate feedstuffs can be fed to supplement roughage, but often cause digestive disturbances (Romberg et al. 1970); therefore changes to concentrate diets must be made gradually over a period of several weeks. During this introductory feeding period, the ration composition should also be modified on a gradual basis from an initial 20:80 w/w concentrate to roughage diet until the desired formulation is obtained.

Cereal grains are ideal concentrates because they have a high energy content per unit weight and owing to their compactness can be transported at a lower cost per unit of digestible energy than other feedstuffs. Consequently, when pasture quality declines to roughage status, cereal grains provide the cheapest and most convenient source of supplementary feed. In addition, recent research has shown that where grain constitutes a significant proportion of the diet, there are some advantages, other than economic, in feeding whole grain in preference to processed grains. The processing of grain, particularly smallgrained cereals, appears to reduce tactile stimulation of the rumen which, in turn, reduces the rate of rumen fluid passage, restricts intake (Weston 1974), produces lower rumen $\mathrm{pH}$, affects cellulose digestion, and increases rumen propionic acid levels (Ørshov et al. 1974).

Where protein is the limiting nutrient, protein supplements appear to increase both palatability and digestibility of the low quality ration. McCall (1940) observed that approximately 0.2 $\mathrm{kg}$ of linseed cake per $45 \mathrm{~kg}$ of liveweight fed to range lambs and pregnant ewes in combination with range forage was more palatable and digestible than the roughage when fed alone. Similarly, Briggs et al. (1960) found that the addition of 3 to $6 \mathrm{~g}$ of urea per head per day to a wheat-roughage ration significantly improved roughage consumption. However, the efficient utilization of protein in ruminants fed roughage diets of low digestibility is dependent on careful selection of the type of protein supplement, since under protein-deficient conditions rumen microbial flora will change considerably (Weston 1971).

While vegetable proteins such as soybean meal, linseed cake, or cottonseed meal are generally most efficient as a supplement to roughage, their expensiveness often limits the feasibility of use in rangeland situations. As an alternative, nonprotein nitrogen (NPN) sources can be used to advantage. Urea is the most common NPN which has produced satisfactory responses in both sheep and cattle, although the response levels are inferior to those recorded with vegetable protein sources. Nevertheless. urea does provide a cheap source of dietary nitrogen. Hassan and Mukhtar (1971) calculated that $2.7 \%$ of urea in a diet could replace about $25 \%$ cottonseed meal and produce a comparable response. Morris (1968) reported a reduction in liveweight losses in yard-fed sheep by supplementing bush hay or sorghum silage with urea, although Briggs et al. (1960) showed that responses were small when the intake of urea exceeded $9 \mathrm{~g}$ per head per day.

Animal performance on urea-based rations is often lower than desired because urea is rapidly hydrolysed and much of the ammonia produced in cxcess of the available energy supplied is lost (Bloomfield and Muhrer 1960). This can cause urea toxicity, although this seems only to be a problem when sheep are being accustomed to the diet (Briggs et al. 1960). Johnson and Clemes (1973) reported that the efficiency of utilization of NPN in conjunction with low quality roughage may possibly be increased with biuret since the release of ammonia is slower than that of urea.

In some situations, deficiencies of both protein and energy may occur and as a consequence the standing herbage provides only "bulk" material with little nutritional value. For example, Mulholland et al. (1976) found no response to urea supplementation of cereal stubbles in grazing sheep even though the intake was deemed adequate. They concluded that the small amount of energy in the pasture and supplement ingested was adequate, hence limiting the impact of urea on production. To utilize this material necessitates supplementation with both protein and energy sources. Research has shown that molassesurea mixtures can fulfill this requirement. Williams et al. (1959) noted increases in roughage consumption and reductions in liveweight loss of sheep that were fed oaten straw sprayed with a molasses-urea mixture. While such responses are not uncommon, the adaptation of sheep to the urea-molasses mixture is prolonged and intake tends to be variable when compared with responses to supplementation with quantities of soybean meal or whole barley grain (Hadjipanayiotou et al. 1975) providing an equivalent nitrogen level.

In practice, some individuals perform poorly on high concentrate diets. This is normally attributed to variation in intake between individuals which may, in some instances, reflect social interactions within the flock structure. Improvement in performance can be gained by less frequent feeding or by removing poor performing individuals and feeding them a diet higher in roughage (Davis et al. 1976).

\section{Physical Form of Diets}

The physical form of the principal components of a supplementary diet is as important as the formulation itself because form can significantly affect its palatability to animals and the degree to which they can digest the material. While some change in physical form is required to satisfactorily conserve fodder (for example, baling hay), other changes such 
as grinding, pelleting, and wafering aim to improve forage value (Minson 1963) by altering performance characteristics such as intake, weight gain, efficiency of feed utilization, and digestibility of the nutrients containcd in the feed (Beardsley 1964)

Pelleting is the most drastic physical change to which forage is subjected commercially, with long hay being finely ground and reconstituted under both heat and pressure. While long forage or baled hay appear to have little consistent effect on animal responses, pelleting the same ration considerably improves sheep performance (Beardsley 1964). This positive response may be due to the grinding, heat, and application of pressure, which render the ration more suitable to the rumen physiology. Meyer et al. (1959) concluded that grinding is probably the major factor which increases consumption of pelleted hay. whereas the pelleting process increases palatability and to some extent increases feed utilization through alteration of rumen VFA production.

However, irrespective of which factor is responsible, increase in intake appears to be the major factor for improving animal performance on pelleted rations (Minson 1963). Meyer et al. (1959) reported that higher consumption was stimulated by reduced prehension and mastication time, increased rate of fermentation. and more rapid production of organic acids. Hence, the rate of passage is increased and more space is available in the rumen, which, in turn, increases animal intake.

With higher intake of pelleted forage, a smaller proportion of the diet is required for maintenance, which leads to the observed improvement of 4 to $8 \%$ in feed conversion. However, there is evidence (Beardsley 1964) that there is an optimum proportion of forage to concentrate for maximum gains. If a high percentage of concentrate is fed in pellets, intake and gain are depressed, even though efficiency of conversion is increased. Nevertheless. McCroskey and Pope (1960) stressed that increases in conversion efficiency is the most important factor in the improved gains from pelleting a high roughage mix. Minson (1963) cautioned, however, that the magnitude of response to pelleting varies with the quality of unpelleted forage with large responses usually obtained by pelleting poor quality forage, but only small improvements when forage quality is high.

Although research has shown substantial increases in gain by feeding pelleted rations, rumen abnormalities have been noted in sheep nourished on various pelleted diets. While no definite conclusions can incriminate pelleted rations in the incidence of ruminal parakeratosis, Moore (1963) suggested that fineness of grind and heat application in the pelleting process are predisposing factors in the development of the disorder. However, there is a strong suggestion (Cullison 1961; Brooks et al. 1962) that feeding a small proportion of long hay with pelleted rations may overcome some of the negative effects.

Wafers are another form into which long hay can be processed. Generally, wafers consist of long or coarsely chopped material which is highly compressed into cubes 1 to 4 inches in length or spheres 2 to 3 inches in diameter. While research on the nutritional value of feeding wafered rations is limited, result tend to follow those of pelleted diets with increased intake emanating from their greater acceptability to livestock and higher digestibility that unprocessed foodstuffs. Although it was intially believed that wafering would reduce some of the ruminal disorders encountered with pelleting, it appears that further data is required to substantiate this belief (Moore 1963).

\section{Frequency of Feeding}

Finally, next to the formulation and physical form of the dietary components, frequency of feeding is important because it provides another regulatory practice which the rancher has at his disposal to manage for optimal response to supplementation. While some workers (Gordon and Tribe 1952) have reported increases in liveweight gains, digestibility, and nitrogen balance for sheep fed at frequent intervals, others have found no difference in these parameters that can be attributed directly to feeding strategies (Ørshov and Allen 1961; Faichney 1968). $\varnothing$ rshov and Allen (1961) explained that differences in results could possibly be an effect of conditions under which experiments were conducted or that response to frequency of feeding might be more sensitive at or about the maintenance level of feeding, and in rapidly growing animals. This is supported by studies conducted by Rakes et al. (1961), who observed that the rate of fattening in adult sheep was independent of feeding frequency, whereas young animals gained $65 \%$ more weight over a 50-day period when fed frequently.

The extent of digestion of forage varies with the time for which digesta are retained in the alimentary tract, which, in turn, varies with the level of feeding (Blaxter et al. 1956) and form of the diet (Meyer et al. 1959). If meals are so infrequent that several days fasting intervene, survival of rumen microbes becomes important. Both Moir and Somers (1957) and Putman et al. (1961) reported changes in the microbial populations of the rumen associated with variation in the frequency of feeding. In addition, infrequent feeding results in decreased digestibility in the rumen (Graham 1967). Thus, with roughage diets, weekly feeding is a disadvantage for maintaining liveweight because rumen digestibility is depressed and the overall net energy of the diet is decreased. For practical feeding, Franklin (1962) suggests that twice-weekly feeding of most livestock classes will produce results equally as good as daily feeding at the same level of intake. However, it must be appreciated that the amount of wastage is likely to be higher for animals infrequently fed in confined enclosures.

Finally, in cases where supplementary feeding may involve considerable additional labor, feed concentrates may be supplied to sheep by self-feeders. While this procedure may economize on labor, per head consumption is more difficult to control, a factor which may result in "replacement" rather than "supplementary" feeding, although in some instances salt additives can be used to effectively regulate intake.

\section{Conclusion}

Since both the quantity and quality of range vegetation available to grazing sheep varies appreciably with climatic regimes, supplementary feeding strategies provide the pastoralist with a management procedure which can stabilize nutrient intake at acceptable levels. In addition to the direct effects on sheep health and productivity, supplementation will reduce the effect of overgrazing as supplementary rations will substantially reduce forage intake, particularly when pasture is sparse. While economics will generally dictate the type of ration formulated, the decision of when to feed and what animals to nourish will be made by the rancher. These decisions can only be made with an appreciation of the expected responses to supplementation of different classes of sheep, as well as a knowledge of the short and long term consequences resulting from inadequate 
nutrition. Without this information, the producer can only implement supplementary feeding strategies on an ad hoc basis which may result in poor animal responses and uneconomic returns.

\section{Literature Cited}

Allden, W.G., and A.C. Jennings. 1969. The summer nutrition of immature sheep. The nitrogen excretion of grazing sheep in relation to supplements of available energy and protein in a Mediterranean environment. Aust. J. Agr. Res. 20: 125-40.

Andrew, R.P., and E.R. Ørshov. 1970. The nutrition of early wcaned lambs 1. Influence of protein concentration, feeding level and sex on body composition at two liveweights. J. Agr. Sci. Camb. 75: 11-18. Annison, E.F., and D.G. Armstrong. 1970. In: Physiology of Digestion and Metabolism in the Ruminant. (Ed.) A.T. Phillipson, Oriel Press, Newcastle-upon-Tyne, p 422.

Argle, LaMar. 1956. "An analysis of productivity in range ewes wintered with weanling lambs under farm and range conditions. MS Thesis. Utah State Agricultural College.

Armstrong, D.G., and J.H.D. Prescott. 1971. In: "Lactation" (Ed.) I.R Falconer, Butterworths, London, p 349.

Beardsley, D.W. 1964. Symposium on forage utilization: Utilization of forages as affected by physical form. 2. Beef cattle and sheep studies. J. Anim. Sci. 23: 239-45.

Blaxter, K.L. 1967. The Energy Metabolism of Ruminants. 2nd Edition, Hutchinson \& Co Ltd., London.

Blaxter, K.L., N. Mc. Graham, and F.W. Wainman. 1956. Some observations on the digestibility of food by sheep and some related problems Brit. J. Nutr. 10: 69-91.

Bloomfield, R.A., and M.E. Muhrer. 1960. Kinetics of urea metabolism in sheep. J. Anim. Sci. 19: 1248.

Briggs, P.K., E.J. McBarron, T.E. Grainger, and M.C. Franklin. 1960. Urea for sheep on poor roughage. Proc. VIII Int. Grassld. Congress, Reading Berks., July 1960 , p 579-83.

Brooks, O.L., W.J. Miller, E.R. Beaty, and C.M. Clifton. 1962. Pcrformance of dairy cows fed pelleted and baled coastal Bermudagrass and alfalfa hay. J. Dairy Sci. 45:

Campbell, R.J., D.G. Saville, and G.E. Robards. 1973. Evaluation of natural annual pastures at Trangie in Central Western New South Wales. I. Sheep production. Aust. J. Exp. Agr. Anim. Husb. 13: 238-44. Clanton, D.C. 1957. The effects of level of nutrition on pathology and productivity of range ewes. Ph.D. Thesis, Utah State Agr. College. Logan.

Clanton, D.C., and W.W. Rowden. 1963. Cobalt supplementation on Nebraska range. J. Range Manage. 16: 16-17.

Cullison, A.E. 1961. Effect of physical form of the ration on steer performance and certain rumen phenomena. J. Anim. Sci. 20: 478-83.

Davies, J.G., A.E. Scott, and J.F. Kennedy 1938. The yield and composition of a Mitchell grass pasture for a period of 12 months. J. Counc. Sci Ind. Res. Aust. 11: 127-39.

Donald, C.M., and W.G. Allen. 1959. The summer nutrition of weaner sheep. The deficiencies of the mature herbage of sown pasture as a feed for young sheep. Aust. J. Agr. Res. 10: 199-218.

Esplin, A.C., M.A. Madsen, and R.W. Phillips. 1940. Effects of feeding ewe lambs during their first winter. Utah Agr. Exp. Sta. Bull. 292.

Faichney, G.J. 1968. The effect of frequency of feeding on the utilization of roughage diets by sheep. Aust. J. Agr. Res. 48: 813-19.

Ferguson, K.A. 1962. The influence of dietary protein percentage on growth of wool. Nature, Lond. 184: 907.

Ferguson, K.A. 1962. The efficiency of conversion of feed into wool. In: The Simple Fleece. (Ed.) A. Barnard, Melbourne Univ. Press in assoc. with Aust. Nat. Univ. p 145.

Ferguson, K.A., H.B. Carter, and M.H. Hardy. 1949. Studies of comparative fleece growth in sheep. Aust. J. Sci. Res. B2: 42-81

Franklin, M.C. 1962. Drought. In: The Simple Fleece. (Ed.) A. Barnard, Melbourne Univ. Press in assoc. Aust. Nat. Univ. p 267.

Franklin, M.C., P.K. Briggs, and G.L. McClymont. 1964. Early weaning of Merino lambs during drought. Aust. J. Exp. Agr. Anim. Husb. 4: 132-40.

Franklin, M.C., R.L. Reid, and I.L. Johnson. 1948. Studies of dietary and other factors affecting the serum calcium levels of sheep. Counc. Sci. Ind Res. Aust. Bull. 240.

Gordon, J.G., and D.E. Tribe. 1952. The importance to sheep of frequent feeding. Brit. J. Nutr. 6: 89-93.

Graham, N.Mc., and T.W. Searle. 1970. Efficiency of utilization of energy by lambs. Proc. Aust. Soc. Anim. Prod. 8: 263.

Graham, N.Mc. 1967. Effects of feeding frequency on energy and nitrogen balance in sheep given a ground and pelleted forage. Aust. J. Agr. Res. 18 467-83.
Hadjipanayiotou, M., A. Louca, and M.L. Lawlor. 1975. A note on the straw intake of sheep given supplements of urea-mollasses, soya bean meal, barley-urea or barley. Anim. Prod. 20: 429-32.

Hadjipieris, G., J.G.W. Jones, R.H. Wimble, and W. Holmes. 1966. Studies on feed intake and feed utilization of sheep. 2. The utilization of feed by ewes. J. Agr. Sci. Camb. 66: 341-49.

Hardy, M.H., and A.G. Lyne. 1956. Pre-natal development of wool follicles in Merino sheep. Aust. J. Biol. Sci. 9: 423-41.

Hafez, E.S.E. 1952. Studies on the breeding season and reproduction of the ewe. 2. The breeding season in one locality. J. Agr. Sci. 42: 199-231.

Harris, L.R. 1960. Forage intake, energy measures and supplementary feeding on the arid areas of the Great Basin. Proc. VIII Int. Grassld. Congress. Reading, Berks., p 574

Hart, G.H., H.R. Guilhert, and H. Gross. 1932. Seasonal changes in the chemical composition of range forage and their relation to the nutrition of animals. Calif. Exp. Sta. Bull. 543.

Harvey, J.M. 1952. The nutritive value of some Queensland fodders. Qld. J. Agr. Sci. 9: 169-84.

Hassan, H.M., and A.M.S. Mukhtar. 1971. A note on the utilization of urea by Sudan Desert sheep. Anim. Prod. 13: 201

Hogan, K.G., D.F.L. Money, D.A. White, and R. Walker. 1971. Weight responses of young sheep to copper and connective tissue lesions associated with the grazing of pastures high molybdenum. N.Z. J. Agr. Res. 14: 687701

Hoversland, A. 1954. Lamb mortality as affected by the nutrition of the ewe during gestation. Mont. Nutr. Conf. Proc. 5th. Annu. Rep. p 118-121.

Hutchinson, K.J., and R.B. Porter. 1958. Growth and wool production of Merino hoggets related to grazing intake in a South Australian environment. Proc. Aust. Soc. Anim. Prod. 2: 33-41.

Johnson, R.R., and E.T. Clemes. 1973. Adaptation of rumen microorganisms to biuret as NPN supplement to low quality roughage rations for cattle and sheep. J. Nutr. 103: 494-502

Lee, G.R., and W.E.M. Rothwell. 1966. Effect of grazing lucerne supplements and stocking rates on sheep and natural pasture productivity in Queensland Traprock Region. Progr. Rep. 1962-65. Qld. J. Agr. Sci. 23: 287-97.

Lee, H.J., and H.R. Marston. 1969. The requirement for cobalt of sheep grazing on cobalt-deficient pastures. Aust. J. Agr. Res. 20: 905-18.

Leng, R.A., R.M. Murray, J.V. Nolan, and B.W. Norton. 1973. Australian Meat Research Committee Review, No. 15, p 1.

Lofgreen, G.P., and W.N. Garrett. 1968. A system for expressing net energy requirements and feed values for grazing and finishing beef cattle. J. Anim. Sci. 27: 793-806.

Marston, H.R. 1932. Studies on supplementary feeding of Merino sheep for wool production. Counc. Sci. Ind. Res. Aust. Bull. 61.

McCall, R. 1940. The digestibility of mature range grass and range mixtures fed alone and with supplements. J. Agr. Res. 60: 39-50.

McCroskey, J.E., and L.S. Pope. 1960. Further studies on pelleting rations for steers. Okla. Agr. Exp. Sta. Misc. Publ. 57: 96.

McDonald, I.W. 1962. Nutrition of wool-producing sheep. In: The Simple Fleece. (Ed.) A. Barnard, Melbourne Univ. Press in assoc. Aust. Nat. Univ, p 122

Michalk, D.L. 1977. Grazing management of dryland lucerne in the Macquarie region of New South Wales. M.Sc. Thesis, Univ. New South Wales, Kensington, Australia.

Meyers, J.H., W.L. Weir, J.B. Dobie, and J.L. Hull. 1959. Influence of the method of preparation on the feeding value of alfalfa hay. J. Anim. Sci. 18: $976-82$.

Miller, W.J., C.M. Clifton, J.K. Miller, and P.R. Fowler. 1965. Effects of feeding unlike forages, singly and in combination on voluntary dry matter consumption and performance of lactating cows. J. Dairy Sci. 48: 104652.

Ministry of Agriculture, Fisheries, and Food. 1975. Energy allowances and feeding systems for ruminants. Tech. Bull. 33, London, Her Majesty's Stationery Office.

Minson, D.J. 1963. The effect of pelleting and wafering on the feed value of roughages-a review. J. Brit. Grassld. Soc. 18: 39-

Moir, R.J., and M. Somers. 1957. Ruminal flora studies. 8. The influence of rate and method of feeding ration upon its digestibility, upon ruminal function and upon ruminal population. Aust. J. Agr. Res. 8: 253-65.

Moore, I.A. 1964. Symposium on forage utilization: Nutritive value of forages as affected by physical form. 1. General principles involved in ruminants and effects of feeding pelleted or wafered forage in dairy cattle. J. Anim. Sci. 23: 230-38.

Morris, J.G. 1968. Nutritional aspects of the survival feeding of beef cattle. Proc. Aust. Soc. Anim. Prod. 7: 20-39. 
Moule, G.R. 1954. Observations on mortality amongst lambs in Queensland. Aust. Vet. J. 30: 153.

Mulholland, J.G., J.B. Coombe, M. Freer, and W.R. McManu. 1976. An evaluation of cereal stubbles for sheep production. Aust. J. Agr. Res. 27: 881-93.

Myers, L.F. 1967. Assessment and intcgration of special purpose pastures. 1. Theoretical. Aust. J. Agr. Res. 18: 235-44.

Norman, M.J.T. 1968. The performance of beef cattle on different sequences of Townsville lucerne and native pasture at Katherine, N.T. Aust. J. Exp. Agr. Anim. Husb. 8: 21-25.

Norman, M.J.T., and G.A. Stewart. 1967. Complementary grazing of native pasture and standing Townsville lucerne in the dry season at Katherine, N.T. Aust. J. Exp. Agr. Anim. Husb. 7: 225-31.

Oddy, V.H. 1978. Feeding sheep and cattle. A system for calculation of feed requirements for cattle and shecp based on metabolizable energy. N.S.W. Dep. Agr., Agr. Tech. Bull. (in press).

Orr, J.B., and A. Holm. 1931. Economic Advisory Council of Great Britain on Mineral Content of Pasture, Sixth Report.

Crshov, E.R., and D.M. Allen 1966. Utilization of salts of volatile fatty acids by growing sheep. 3. Effect of frequency of feeding on the utilization of acctatc and propionate by young growing lambs. Brit. J. Nutr. 20: 509 32.

Ørshov, E.R., C. Fraser, and J.G. Gordon. 1974. Effect of processing of cercals on rumen fermentation, digestibility, rumination time, and firmness of subcutaneous fat in lambs. Brit. J. Nutr. 32: 59-69.

Parker, G.V., and C.J. Thwaites. 1972. The effects of undernutrition on libido and semen quality in adult Merino rams. Aust. J. Agr. Res. 23:109-15.

Putman, P.A., J. Gutierrez, and R.E. Davis. 1961. Effects of frequency of feeding upon rumen volatile acids, protozoal populations and weight gains in Angus heifer calves. J. Dairy Sci. 44: 1364-65.

Rakes, A.H., E.E. Lister, and J.T. Reid. 1961. Some effects of feeding frequency on the utilization of isocaloric diets by young and adult sheep. $J$. Nutr. 75: 86-92.

Richards, G.S. 1942. Effects of supplemental feeding at breeding time on fertility in range ewes. MS Thesis, Utah State Agri. College.

Robards, G.E., and G.R. Pearce. 1975. Provision of high nitrogen roughage to sheep as a supplement to low nitrogen roughage. Aust. J. Exp. Agr. Anim. Husb. 15: 342-56.

Romberg, B., G.R. Pearce, and D.E. Tribe. 1970. Growth and carcase quality of lambs fed concentrate rations in a feedlot. Aust. J. Exp. Agr. Anim. Husb. 10: 145-56.

Ryder, M.L., and S.K. Stephenson. 1968. Wool Growth. Academic Press, London.

Saville, D.G. 1978. Maintenance feeding of grazing animals. In: World Animal Science, Vol. 16- "Grazing Animals." Elsavier Sci. Publ. Co.. Amsterdam, (in press).
Schinckel, P.G., and B.F. Short. 1961. The influence of nutritional level during pre-natal and early post-natal life on adult fleece and body characters. Aust. J. Agr. Res. 12: 176-202.

Stoddart, L.A., A.D. Smith, and T.W. Box. 1975. Range Management. 3rd Edition. McGraw-Hill Book Company, New York.

Thompson, W., and A.M. Thompson. 1948. Lambing in relation to the diet of the pregnant ewe. Brit. J. Nutr. 2: 290-302.

Thornton. R.F., and D.G. Minson. 1972. The relationship between voluntary intake and mean apparent retention time in the rumen. Aust. J. Agr. Res. 23: 871-77.

Tilton, W.A., A.C. Warnick, T.J. Cunha, P.E. Loggins, and R.C. Shirley. 1964. Effect of low energy and protein intake on growth and reproduction performance of young rams. J. Anim. Sci. 23: 645-50.

Topps, J.H. 1972. Urea or biuret supplements to low protein grazing in Africa. World. Anim. Rev. 3: 14-18.

Treacher, T.E. 1971. Effects of nutrition in pregnancy and in lactation on milk yield in ewes. Anim. Prod. 13: 493-501.

Vercoe, J.E., D.E. Tribe, and G.R. Pearce. 1961. Herbage as a source of digestible organic matter and digestible nitrogen for the grazing sheep. Aust. J. Agr. Res. 12: 689-95.

Watkins, N.E. 1937. The calcium and phosphorus content of important New Mexico range forages. New Mexico Agr. Exp. Sta. Bull 246

Watson, R.H. 1962. Reproduction in sheep. In: The Simple Fleece. (Ed.) A. Barnard, Melbourne Univ. Press in assoc. Aust. Nat. Univ.

Watson, R.H., C.S. Sapsford, and I. McCance. 1956. The development of the testes, epididymis and penis in the young Merino ram. Aust. J. Agr. Res. 7: 574-90

Weston, R.H. 1971. Factors limiting the intake of feed by sheep. 5. Feed intake and the productive performance of thr ruminant lamb in relation to the quality of crude protein digcsted in the intestines. Aust. J. Agr. Res. 22: 307-20.

Weston, R.H. 1974. Factors limiting the intake of feed by sheep. 8. The roughage requirement of the ruminant lamb fed on concentratc diets based on wheat. Aust. J. Agr. Res. 25: 349-62.

Whitcomb, E.H. 1952. The effects of feeding protein, phosphorus, and energy to ewes on winter range. MS Thesis, Utah State Agr. Coll. Logan.

Williams, N.M., G.R. Pearce, M. Delaney, and D.E. Tribe. 1959. The growth and appetite of sheep on high fibre, low-protein supplemented with urea and molasses. Emp. J. Exp. Agr. 27: 107-16.

Willoughby, W.M 1959. Limitations to animal production imposed by seasonal fluctuations in pasture and management procedures. Aust. J. Agr. Res. 10: 248-68.

Young, B.A., and J.L. Corbett. 1972. Maintenance energy requirements of grazing sheep in relation to herbage availability. 1. Calorimatric estimations. Aust. J. Agr. Res. 23: 57-76.

Research Associate Wanted: Available immediately. Located at San Angelo. Pay $\$ 12,000$ to $\$ 15,000$ per year, depending on qualifications. Must have M.S. degree and be able to do research with minimum supervision. - Control and management of toxic rangeland plants-For details contact: Dr. Darrell N. Ueckert, Texas A\&M University Agricultural Research and Extension Center, Rt. 2, Box 950, San Angelo, Texas 76901.

Head, Department of Animal and Range Sciences. Required: Ph.D. in Range Science, Animal Science, or closely related area and experience in teaching and research. Administrative and extension experience and ability to effectively relate to Montana livestock and range industries is highly desirable. Position effective July 1, 1980. Application deadline is December 15, 1979. Nominations and requests for application information should be sent to: Dr. R.W. Whitman, Animal and Range Sciences, Montana State University, Bozeman, Montana 59717. 